\title{
Preparing TVET Teacher Competence through Industry Practice Process
}

\author{
I. W. Ratnata \\ Department of Electrical Engineering \\ Universitas Pendidikan Indonesia \\ Bandung, Indonesia \\ i_wayan_ratnata@yahoo.com
}

\begin{abstract}
Entering the year 2016 all ASEAN's countries have to be ready to face the MEA era, namely era for competition for various sectors, certainly through healthy competition, and fair. Indonesia constitutes one of ASEAN's countries and with the number of 250 million populations should be ready to deal with various competitions. Currently, trending issues developing in Indonesia are related to low skills of workforces and worrying that they will be difficult to compete with other workforces around ASEAN's countries. Related to the increase the skills for human resources, vocational teachers' role constitutes crucial aspects that should be paid attention by government. This research, attempted to provide solutions to enhance competence the vocational teachers' candidates through appropriate process when they are still at university. The research was conducted in Department of Electrical Engineering Education, Faculty of Vocational and Technology Education, Indonesia University of Education and in some industries in Bandung Indonesia, where students performed industrial internship (industrial work practice). This research used descriptive research, and the aim of the research is to produce vocational teachers that possess good knowledge and skills according to their study field. Associated with the industry internship process to enhance TVET teacher students, university (the world of education) should build good cooperation to the world of industry through three stipulations that should be met, namely: memorandum of understanding (MoU) between the world of education and the world of industry; university possesses study program related to the world of industry; and industry possesses enough facilities and equipment for conducting industrial internship.
\end{abstract}

Keywords: industrial practice, TVET teachers, MoU

\section{INTRODUCTION}

The year 2016 constitutes the year of hard working to face the era of ASEAN Economic Community (AEC). All ASEAN's countries have to be ready to deal with variety of competitions that will occur in the regions. Talking about competitions overall is highly driven by human resources sectors. Even though a country has huge natural resources, the country cannot compete with other countries if the resources are not managed and processed by good and quality human resources. In this context, one aspect to have good quality of human resources is that educational sector in the country should be well managed.
Recently, the issues emerging amid society are in the context of teacher's quality. An interesting topic on national newspaper of Harian Pikiran Rakyat, Soefijanto T. A. (June 25, 2015) [1], highlighting about teachers are not ready to face the 21th century. Additionally from the research in 2014 done by ACDP (Analytical and Capacity Development Partnership) on national newspaper of Harian Pikiran Rakyat, ( June 26, 2015) it is said that there is no evidences the teacher certification program that has been carried out by government is able to make teachers to teach better [2]. Responding these conditions, there are some shortcomings and weaknesses in educational system primarily teaching and learning process in the world of education in Indonesia.

In the educational system, Indonesia has applied a regulation that the requirements of teacher should have not only have bachelor background but also have certification for teaching. Looking at the requirements have been stipulated, it should not be much of a problem to be experienced in educational sector in the country. The most important aspect should be noticed with respect to the educational system in order to have good teacher in teaching. Associated to the stipulations in teacher and lecturer act, a teacher should have competency in pedagogic, professional, personality, and society. In order possess these competencies, he must undergo various processes in the context of teaching and learning processes that can bring about good results in educational process.

Vocational education and training (VET) in some countries especially for developing countries is still difficult to develop, because of some obstacles they have. Even, in European Union countries in improving the quality of their vocational educational system still have to look for comparison to some in ASIA, like Russia, China, India and Korea [3]. In education process in order to have a change, there should do innovations according to the development of technology.

To have good quality of teachers, higher education which is producing teachers in this context is the vocational teacher education should draw up good curriculum according to demands the world of work. As known that graduates of vocational teacher education in which prepared to be teachers in VET school and of course they have to have good competence (knowledge and skill) to teach. Up to now, there still hear that fresh graduates produced from vocational teacher 
educations are not ready to teach for vocational fields, it is highly worrying. Even experts said that Vocational teacher educational graduates are not ready to teach in vocational school. There are some shortcomings and weaknesses that should be addressed soon. We know that in developing countries, mostly people are in low and medium economic class (level), they need a job soon after graduating from vocational school, and of course still giving opportunity for those people who want to continue to higher education (tertiary education).

\section{ISSUES DEVELOPING WITHIN PREPARING SKILLED WORKFORCE}

Teacher is as key pillar in developing human resources, we can imagine that without having good teacher what kind of human resources should be built. A good teacher must be able to build pupils to be adult and mature and self-reliant or stand alone. A good teacher must have competencies, namely: pedagogic competence, professional competence, personal competence, and social competence (Teacher and lecturer Act, 2005) [4]. Up to now that a great challenge is faced by especially for vocational teachers where they must be able to answer various challenge relating to the technology development.

Teachers in current era have heavy duties, where they must be able to follow the development of technology so fast. Teachers should literate to the advancement of ICT in order they can obtain knowledge, even it is likely teachers will be defeated by students. Accordingly, as advanced teachers cannot stay in place and regard themselves as good teachers, it is not anymore. Therefore, to prepare vocational teachers, since early, as vocational educational students should be introduced the world of technology and industry in order they are ready to be vocational teacher.

\section{A. Lack facilities for practicum or practices}

In general that facility for practicum in the world of education is less than industry. Talking concerning vocational teachers in which they will teach students and give them skill in order they have competency in installing, operating, and maintaining machineries or electrical installation, etc. Therefore, teachers should be equipped and given skill in their field. Actually vocational teachers should have high skills in their field. Basically, as vocational teachers must have knowledge and skill relating to the industries. Therefore since early, vocational teacher students should be introduced the world of work or industry.

\section{B. Strategy to approach with industry}

Cooperation with industries should be done by the world of education, primarily for educational institutions that produce vocational teacher hopefuls. Doing approaches with industries or companies is not easy, required a good strategy in order cooperation for institutions, educational institutes and industries can run well and harmonically. In creating cooperation with industry cannot get just profitable in one side and should be both sides. For education institutes should assist in doing research in order productivities, efficient, and profit for industry increase. Within other sides for industries, in which they can give and accept students doing apprenticeship, research and other activities can get profitable for two sides.

In doing cooperation with the world of industry or company should build a good communication between industry and education institute, and this cooperation should be built in a form of memorandum of understanding (MoU). So far, in general, many educational institutes build cooperation through MoU but after doing signature in between two sides not be followed with concrete action. For example, experts or lecturers or students in university should do research and help for increasing productivity in industry. According to the interview with instructors or industrial communities, that every semester many students propose to be able to take part in doing industrial practices, and some of them were refused because of various reasons or considerations. If university has letter of intent in a form of $\mathrm{MoU}$, it is expected that difficulties for students doing industrial practice can be minimized and even omitted.

\section{LITERATURE REVIEW}

In our life, learning is an important thing that should be done in order we are able to face for every challenge on current situation and the future. We frequently hear lifelong education, and it means that we never stop learning. Having knowledge and capabilities or competency just can be achieved through learning. According to Dahar (1989, page 21) [5], learning is defined as a change of behavior through experiences. Therefore, knowledge and ability of someone can be achieved along with or through real experiences what he is doing .

Referring with a theory of mental discipline from Plato and Aristotle (Butler D.J, 1968, page 249 -252) [6], pupils are taught disciplines through environmental conditions. If we look at the behavior theory by Ivan Pavlop and the theory of classical conditioning in which the changes of mental of someone caused by environmental conditions (Dahar, 1989, page 23). If looked at from the learning theories above where the changes of someone behavior highly influenced by environmental condition, so that in order student have a lot of knowledge not just found in campus but can also get from out of campus like industries, companies or other job places.

Thorndike is known for behavior's theory, that behavior as process against stimulus within environment (Dahar, 1989, page 23-24). It means that someone will study intently if he brings to the reality, and he can look at what is going on, what happen and can perceive the objects. Through this condition, student will have spirits to study and also wants to know and learn the technology used in industry and linking with theory that he has learned. Paying attention of the theory above, it is clear that in learning is highly influenced by environment where someone lives, what he sees and perceives. Therefore, coming students to workplace or industry constitutes proper steps to apply the knowledge that he's got in university. And now the question is the extent to which an educational institution has provided facilities and services to students.

In this regard, educational institution actually has carried out some programs relating to the industrial practice like: internship, apprenticeship, work-industry and others. Currently the problem is being faced related to those activities where still 
have somewhat obstacle. Regarding this issue, it seemingly must exist proper solutions to address issues developing amid society. Novak views (1979:89) [7] that, one's capability can be increased through what he is doing so, and he also says that in order to understand what one knows, the extent to which he has done something. Novak also describes that if someone wants to enhance his competences primarily related to learning processes can be seen on Figure 1 below. Through the figure, that in order to understand a concept well, direct experience like doing activities at workplaces or lab or laboratory or work in studio need to be undergone by someone.

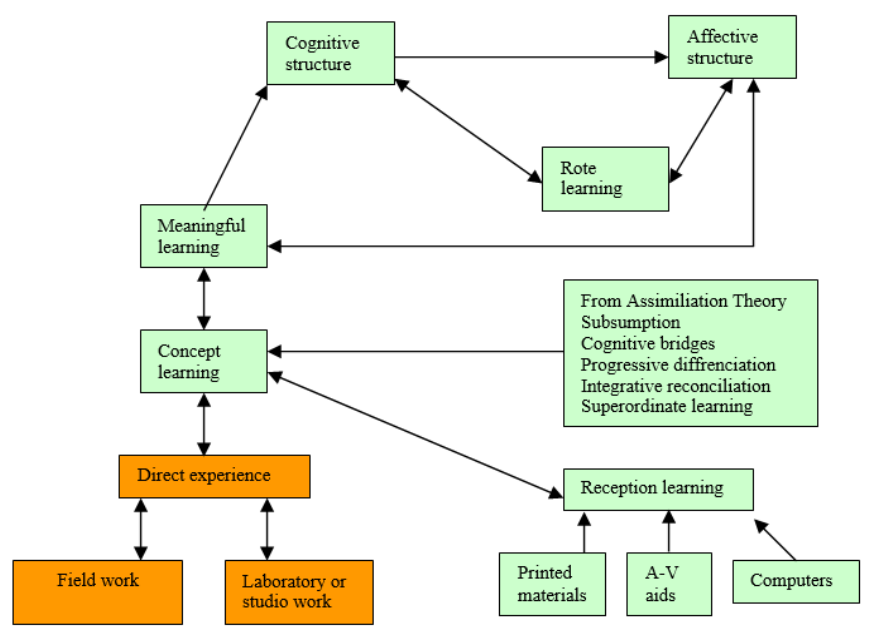

Fig. 1. Conceptual hierarchy for learning (Novak D.J, 1979:87)

As on figure above, we can give the important sense, that after student studying concerning theoretically, he can perceive what happen in workplace or field work and also student doing activities in laboratory. All in this regard, it means student doing direct experience in workplace or industry. In concept learning, besides reception learning through meeting in classroom direct experience is really imperative, and should be taken into consideration in vocational education. Meaningful learning constitutes a shape of learning process which can produce proper model in which not just for general education but also vocational education if noticing figure above. In meaningful learning, also means will involve cognitive structure, affective structure and rote learning. The hierarchy of conceptual learning can be said highly important should be understood by teacher in learning process so that curriculum structure like this should be drawn up in order can bring about into perfect learning and apply not just for general education, but also for vocational education.

\section{PATTERN OF INDUSTRIAL PRACTICE}

Challenges faced students in getting experience according to their study field are still difficult, because the number of industries that relevant to the student study fields. Therefore they should be able to do adaptation with industry where they will be doing industrial practices. Besides that, students who want to carry out of industrial practice is in quite big number, so that industry restricts the number of students in undertaking industrial practice within just certain number.
Up to now, mostly education institutions want to send students to industry for doing industrial practice without having a prior relationship. It is better in between two institutions should have previous cooperation in form a memorandum of understanding, MoU, so that students who will do the activities like doing industrial practice, research and others have no much difficulty.

Looking at what has been carried out by ATMI Michael in Solo [8] and Polman (polytechnic manufacture) Bandung (Moerwismadhi, 2012) [9] - Indonesia can be a model in conducting industrial practice for students. Both education institutions can be used as an example for others in carrying out cooperation with industry. They have made MoU with many industries, besides that in doing their cooperation, students do the job that exist in industry for being done in university's laboratory. Through this activity of course having benefit for industry and university. For industry they getting benefits in reducing budget to pay employees, and for university, students can do advantages in enhancing student knowledge and skills where students can do a job what is in industry. In this activity, it will be benefit for both institutions.

In this research has been done survey some months ago in industry, where researcher did interviews with some technicians and officials in industries like PT. DI (Dirgantara Indonesia, or aircraft company), PT. INTI (Industri Telekomunikasi Indonesia, or Indonesia Telecommunication Industry), and PT. Pindad (Perusahaan Industri Angkatan darat, or weapon industry for military) located in Bandung WestJava. From interviews, obtained the information, that basically industry welcomes students doing industrial practice, however they need to do some procedure should be complied according the rules is in industry. Besides that, the most important thing that should be done by institutions, university and industry should build memorandum of understanding in order that there is a clarification or clearness in conducting the activities of industrial practice for students.

There are some approaches in educational system are frequently used in vocational education to enhance student skills in vocational field.

\section{A. TEFA (Teaching Factory)}

Teaching factory program constitutes a blend in learning between competency based training (CBT) and Production Based Training (PHB). In learning should create a condition like real job and can give students the spirit to learn what they are studying. Through TEFA can shape someone skills because in through this approach to giving a situation like work in industry, where students working real job and produce products according to the market demands.

\section{B. Dual System Education}

The basic concept of Dual System Education is where this concept constitutes cooperation programme between vocational school and industrial partner. Wena (1995, page16) [10] says that dual system education is combination sub-system of education in school and sub-system of education in workplace.

Dual system education is educational system where educational process undertaken in two institutions, in school and workplace or industry. This model has been implemented 
in Germany and the program supported by the world of industry. In this model, students get theory in school and skills in industry through practical work. Dual system education in Indonesia undergoing many problems, additional the number of industries is still limited, and not a lot the industries have advanced technology and provide students doing practical work.

\section{IBL (Industry-Based Learning)}

This learning system is a model of learning involving industry and the world of education. In Swinburne university Australia (http://www.swinburne.edu.au/iel) [11], this program offered on bachelor's level where students given a chance to industrial practice work fully for during 6 or 12 months on relevant job to the study field of students in university.

\section{IIBL (Industrial Incubator Based Learning)}

This learning model designed in synergic between various competences of sciences and constitutes integration between theory and practice into form of small group called incubator. The activity is designed by involving students directly to produce a product starts from preliminary design, concept development, designing system, detail designing, making product, test and review of product up to making business plan for commercializing product that has been produced through theory of marketing strategic that students obtain in classroom in order the product produced can be sold in market (Alva Edy Tontowi, 2004) [12].

\section{E. PBET (Production Based on Education and Training)}

Production Based on Education and Training, PBET, where learning activity done in integration between learning and training process within the activity of production processes as a learning media. In Indonesia, PBET conducted in Polman Bandung and ATMI Michael - Solo.

\section{F. Apprenticeship}

Apprenticeship approach actually has been known for long time, and constitutes the oldest type of vocational education. The Training Standards Councils (2000), published in English which is explained in the text, that more and more young people want to follow on the job training in accordance with the demands of the workplace with the qualification standards is required. By implementing apprenticeship approach in which can balance learning process conducted in school and industry and students will have well knowledge and skills. An architecture for modern apprenticeship, (INAP Commission Architecture Apprenticeship, 2012, page 5) [13] says that, the unique selling point of apprenticeship (or dual vocational education) is the production of people with a high quality and holistic competence in an occupation which is certified through a final assessment of professional knowledge and skills.

In enhancing the teacher competence in his skills related to the vocational field in Indonesia still experiences difficulties. As known that vocational teacher should have good competence in his knowledge of technology and his skill for vocational practice. Vocational teacher should possess capability in high skill field before working as a teacher. If we look at the teacher and lecturer Act in Indonesia, to be a teacher should possess competence within: pedagogy, profession, personality, and social (teacher and lecturer Act, 2005). In this regard professional competence is an importance aspect should be met by a vocational teacher. Keep in mind, in general that vocational teacher in secondary vocational school produced by university where in curriculum the number of practice for students in order to produce good skill is still limited.

If we look at substance of apprenticeship approach model, this approach is one solution to enhance skilled that should be possessed by a vocational teacher. It is hard for teacher to teach in secondary vocational school if he doesn't have vocational skills. A teacher wants to deliver materials in learning process should possess broad insight in technology field and possessing technology should be applied for working. As a vocational teacher educational student should pay attention how important skills that should be possessed by a teacher. Therefore, as teacher candidates since early they prepare their skills by following internship or apprenticeships in the world of work or industry. Through short overview above, the activity of apprenticeship, students will posses: high quility and holistic competence in an occupational field, competence to shape one's work, seeing work context as a constitutive feature of profesional work.

According to the report published by the Training Standards Councils (2000) [14], published in English, which is explained in the text, that more and more young people want to follow on the job training in accordance with the demands of the workplace with the qualification standards is required. By modern apprenticeship system that balances structured learning material vocational qualifications (vocational qualification) and academic knowledge. In these activities are clear organized through the structure of curriculum which can improve students' competence.

Through above approaches if it is well run and consistently make sure that what students doing relating to the industrial practice will produce good result. Up to now, cooperation in between the world education and industry in order that there is mutual interest and mutual respect in relating to practical activity, research and others. This paper drawn up based on research done in industry related to the pattern of industrial practice for vocational education students in order to prepare vocational teachers for vocational school. This research using descriptive research, in which this research aims to describe about situations or events in locations described clearly (Suryabrata S, 1983) [15]. Data collected using questionnaire, survey, and interviews in Department of Electrical Engineering Education and in some industries, like PT. DI; PT. Inti; and PT. Pindad. Through the research found that, there are three points that can be taken into consideration cooperation between university and industry in order that can well run namely, a) exist MoU (memorandum of understanding), b) University that has study field conforms to the work area in workplace / industry, c) industry has job or production related to the study field in university. From the three components can be described like figure 2 . below. 


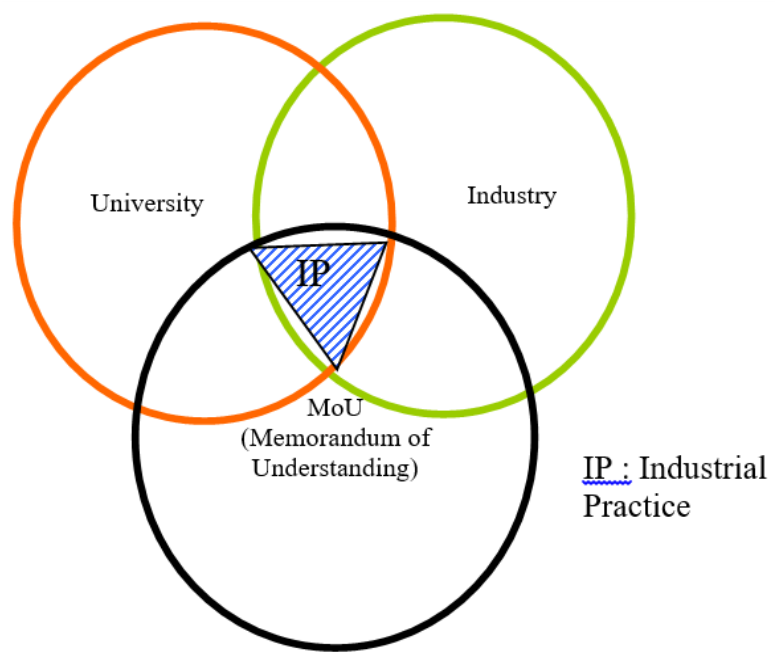

Fig. 2. Three components to run the activity of industrial practice for students

\section{MoU:}

- Agreement (contract) in letter of intent

- Cooperation in research

- Cooperation in building for both sides, education and technology

- The activity of students in doing industrial practice is programmed.

\section{Higher Education:}

- Having enough Staff in the field of engineering

- Having a relevant study programme with industry

- Having practical lab facilities

- Having subject related to industry practice in curriculum

\section{Industry:}

- Industry related to study program in Higher education.

- Industry using technology and machinery for fabrication

- Technicians or instructors in industry can guide and give knowledge and skills to students.

- Industry can work together with university in developing the technology.

Pattern of industrial practice (PI):

- Policy of industry in practical pattern to students

- Pattern of student activity in industry or workplace

- Pattern of mentoring and monitoring from lecturer

- Pattern of training given by instructors or technician

- Pattern of evaluation the industrial practice activity for students.
To increase student skills, it should exist regulations where industries must provide places for students for doing practical work. As an illustration, South Korea's government obligates every industry that employs more 300 employees should provide a chance for students to do practical work.

\section{CONCLUSION}

From above description finally can be drawn up some conclusions:

1. To increase students skills in practical skills according to industry demands and they also have the competences appropriate to teach in vocational school, students should be programmed or obligated in order to do industrial practice in workplaces or industries.

2. To prepare vocational teacher students having high competences in terms of practical activity, since early they should be introduced the world of industry or workplace in order they enjoy their tasks where they will be vocational teachers.

3. In doing cooperation between the world of education and industry should be built a ties in form of MoU in order that there is strong relationships for both sides. By having $\mathrm{MoU}$, the assuredness of students to do industrial practice become clear and the sure to students in the workplace will be better.

4. Basically the world of industry welcomes students to do industrial practice, yet they should bring proposal and other requirements required.

5. Partnership should be created for both institutions (the world of education and industry) to strengthen the position to each other. In doing cooperation, each institution has to give contributions according to its capacity. University gives contribution for human resources in doing research, and industry gives facilities for practical work students, informing the technology development in industry and its implementations. University and industry should build cooperation in technology development and human resources for both sides.

\section{RECOMMENDATION}

Through this research, some recommendations that can be offered as the following bellow:

1. According to the expectation from industry, in conducting cooperation should be based on MoU made from both sides and have to be run consistently.

2. The world of industry expects that in doing industrial practice, students should comply the provision assigned by industry.

3. Students in conducting industrial practice should be monitored by mentor from university, and in industry they are guided by instructors or technicians.

4. In running cooperation should be conducted consistently, for both sides can build and develop human resources and technology in industry and university. 


\section{REFERENCES}

[1] Teacher Not Ready to Face the 21st Century ( Guru tak Siap Hadapi Abad ke-21) on Newspaper "Harian Pikiran Rakyat", Soefijanto T. A. ( June 25, 2015),

[2] Analytical and Capacity Development Partnership on Newspaper of Harian Pikiran Rakyat, Guru Keberatan Program Sertifikat Dicabut, ( June 26, 2015)

[3] Ruth, Klaus; Grollman, Philipp (2009): Monitoring VET Systems of Major EU Competitor Countries, ITB-Forschungsberichte 39/2009. Bremen.

[4] Indonesia Republic Act, No. 14, year 2005, About Teacher and Lecturer, 2006 (Undang-Undang RI No.14 tahun 2005 Tentang Guru dan Dosen, Bandung: Citra Umbara, 2006).

[5] Dahar R. W., 1988, Learning Theories (Teori-Teori Belajar), Penerbit Erlangga.

[6] [6] Butler D.J. 1968, Four Philosopies and Their Practice in Education and Religion, Third Edition, New York, Evanston and London.

[7] Novak, J. D. 1979. A Theory of Education. London : Cornel University Press.
[8] Samodra Y V, 2012, Production Based Education and Training (PBET), ATMI Polytechnic (Politeknik) Surakarta

[9] Moerwismadhi, 2012, Teaching Factory, a Concept to Sutainable Vocational Higher Education Institute, Manufacture Polytechnic (Politeknik Manufature Negeri) Bandung.

[10] Wena, Made, 1996, Dual System Education (Pendidikan Sistem Ganda), Penerbit, Tarsito Bandung.

[11] http://www.swinburne.edu.au/iel

[12] Alva Edy Tontowi, 2014, Development of Industry Incubator Based Learning, , Faculty of Engineering , Industry Technical Department, Gajah Made University, (Pengembangan Pembelajaran Berbasis Inkubator Industri) Fakultas Teknik Jurusan Teknik Industri UGM, Lontar Gajah Mada, Volume 1, no. 2 Juni 2004: http://www.google.co.id/url?sa=t\&rct=j\&q=\&esrc=s\&source=web\&cd= $3 \&$ ved $=0$ CDAQFjAC\&url

[13] INAP Commission, 2012, An Architecture for Modern Apprenticeships, Standard for Structure, Organization and Governance, INAP Commission, 2012.

[14] Modern Apprenticeships, 2000, A Survey Report by The Training Standards Councils

[15] Suryabrata S. (1983), Research Methodology, Publisher CV. Rajawali Jakarta. 